\title{
Sport fandom and parenthood
}

\author{
Julie Tinson, Gary Sinclair, Dimitrios Kolyperas \\ Marketing and Retail Division \\ Stirling Management School \\ University of Stirling \\ Stirling, Scotland UK
}

Correspondence details: Dimitrios Kolyperas, Marketing and Retail Division, Stirling Management, University of Stirling, Stirling, UK. FK9 4LA. Tel: +44 (0) 1786467325 Fax: +44 (0) 1786467400 Email: dimitrios.kolyperas@ stir.ac.uk

Accepted for publication in European Sport Management Quarterly published by Taylor and Francis.

Word count: 12169 
Research question: Sport fandom is acknowledged as offering consumers the opportunity to differentially engage as well as co-create value through network interaction, enhancing social wellbeing and social integration. However, recent research indicates that sport fandom escalates or deescalates over time with calls to examine the intersection of parenting and sport fandom. This research focuses on mothers and fathers and examines how their sport fandom intensifies or declines as a consequence of having and raising children. This research will add to our understanding of fandom by identifying when and under what circumstances sport fandom is a bonding or detaching experience for parents and the role it plays in socialization and consumer behavior.

Research methods: The study adopts a multi-method interpretive qualitative approach, using indepth interviews and an online discussion forum. The sampling frame consists of a total of thirty five parents using two stages of research (Stage $1 n=15$, Stage $2 n=20$ ). Participants are at varying stages of parenthood with single and mixed gender families.

Results and Findings: The study develops a typology of (de)escalating sport fandom during parenthood and differentiates between fandom as pertaining to an individual or social identity. Data also reveals varying dichotomies such as: excess and moderation, risk and reward, individual and shared behaviors (including customer-to-customer interaction) as well as perceptions of allegiance and disloyalty.

Implications: Knowledge of parenting and sport fandom will assist managers in developing effective loyalty schemes and marketing packages and will offer an understanding of the temporal effect of having children on fandom.

Keywords: sport fandom; parenting; self-identity; social identity; children 


\section{Sport fandom and parenthood}

Sport fandom is a multifaceted concept. Being 'a fan' is shaped through what motivates an individual to engage (e.g. escapism, entertainment), the social and experiential nature of fandom (e.g. social integration and acceptance) as well the outcomes of engaging in such activities (e.g. social actualization and social coherence) (See for example: Wann, Tucker, \& Schrader, 1996; Wann \& Weaver, 2009). Sport fandom differs from spectatorship as being a fan involves greater degrees of enthusiasm, emotion and intensity (Hirt, Zillmann, Erickson, \& Kennedy, 1992). Until more recently, sport fandom was considered as a 'static' rather than a continually evolving or (de) escalating activity (Hyatt \& Foster, 2015; Mullin, Hardy, \& Sutton, 2007). This reflects the assumption that the commitment of a sports fan is enduring. Similarly, while sports fans have been identified with varying degrees of engagement, often related to the perceived extent of their commitment (Bernthal, Koesters, Ballouli, \& Brown, 2015; Tapp, 2004; Tapp \& Clowes, 2002) what impacts or disrupts fan loyalty and related consumer behavior is less well understood (Hyatt \& Foster, 2015). Understanding fandom in a sporting context is important as 'sport fandom is one of the preeminent leisure activities in our society today' Dwyer and Drayer (2010, p. 207). The consumption of sport can offer families the opportunity to spend time with one another (Wann et al., 1996), co-create value through customer-to-customer interaction (Uhrich, 2014) as well as facilitate social connections without the need for special skills or expertise (Branscombe \& Wann, 1991).

Researchers emphasize the social well-being sport fandom affords and attribute enhanced self-esteem to collective engagement or related social practices (Wann, 2006; Wann et al., 1996; Wann \& Weaver, 2009). Although being a sports fan can be expressed as part of an individual or social identity, Social Identity Theory (Tajfel, 1979) has most often been used by researchers to explain how and in what ways sports fans are motivated to boost 
their self-esteem through identifying with a successful group (Heere \& James, 2007; Levine, Prosser, Evans, \& Reicher, 2005). More recently Identity Work Theory has been applied to the concept of fandom which underscores the importance of how fans 'ultimately view themselves' as opposed to the team of which they are a fan (Hyatt \& Foster, 2015).

However, identity is dynamic because consumers have a number of self-images (Hogg \& Michell, 1996) and a sports fan identity is only partial as an individual will play other roles e.g. citizen, professional, neighbor etc. The self is always in process and the 'part' of the self which is a sport fan may alter according to significant changes to the life course e.g. parenthood. Therefore the extent to which being a sports fan is underscored or diminished in this context is worthy of further exploration. Although previous studies have examined fandom over time the focus of previous research has typically concentrated on the role of culture (e.g. music, TV series) and not sport (Harrington \& Bielby, 2010). The importance of understanding parenthood and sport fandom is particularly apt as the socialization of children in relation to consumer behavior has already been explored in significant depth and has considered the development of consumer skills as well as related parental styles and the growth of materialism [See for recent examples: Kerrane, Bettany, \& Kerrane, 2015; Richins \& Chaplin, 2015; Wisenblit, Priluck, \& Pirog, 2013]. Conversely how sports fan loyalty is cultivated, neglected or rejected by parents is under-researched. Similarly, there is a lack of empirical research regarding how and in what ways value cocreation and customer-to-customer interaction is developed as a consequence of the influence of parenthood on the sport fandom of children.

Hyatt and Foster (2015) suggest that studying the intersection of parenthood and sport fandom is likely to reveal rewarding insights and specifically question whether being a 'good' sports fan is congruent with being a 'good' parent. As sport fandom has been associated with both male retreat (Klein, 1990), and masculinity (Porat, 2010) this is worthy 
of further investigation. Interestingly research on fathers in leisure pursuits is also minimal (Kay, 2006). Sport consumption as it relates to parenthood has generally been concerned with how mothers and fathers encourage participation in competitive and/or fitness related activities (Trussell \& Shaw, 2012; Wheeler, 2012; Wheeler \& Green, 2014) and their parental styles in encouraging leisure activities (Outley \& Floyd, 2002). Thus, our understanding of the intersection of parenthood and sport fandom is at a very early stage despite the implications this knowledge will have for both marketers and academics.

This study seeks to address the issues raised here and attempts to develop an understanding of how and in what ways sport fandom and parenthood connect using a multimethod qualitative research approach. Using Hunt, Bristol, and Bashaw (1999, p. 440) definition of a sports fan as an 'enthusiastic devotee of some particular sports consumptive object' and Hirt et al. (1992, p. 725) definition of fandom as 'an affiliation in which a great deal of emotional significance and value are derived from group membership' we recognize both individual and social benefits of fan related activities. Similarly while it is understood that the motivations for such pursuits vary (Wann et al., 1996) how these motives change over time requires further exploration. Wells (1993) also suggests that by studying lifealtering effects, e.g. having a child, we will add value to our understanding of consumer behavior.

The purpose of this research is twofold. First, we establish the type of sports fan each parent respondent represents considering their level of commitment and degree of engagement. Such activities will include club (or affiliated) membership, identification with player/s or athletes as well as (non) attendance of events in physical or virtual environments (Bernthal et al., 2015). These behaviors will also be related to expression of individual and social identity. Based on these findings, we explore an understanding of (de) escalating sport fandom as a consequence of parenthood. We develop a typology to categorize relevant 
consumer behaviors as they pertain to sport fandom to offer insights and to afford marketers the opportunity to engage with and manage disruption in sports fans over time.

Second, we explore the role of sport fandom in parenting over time and examine the extent to which parents encourage, neglect or reject such fandom in their child's consumer behavior. This will also offer an opportunity to observe how families co-create value through customer-to-customer interaction at an intra-level (Woratschek, Horbel, \& Popp, 2014). Ward (1974, p. 2) defines consumer socialization as the 'processes by which young people acquire skills, knowledge and attitudes relevant to their functioning as consumers in the marketplace.' Thus, 'fandom socialization' could be used to describe how parents imbue the emotion, meaning and engagement with a sport to their child/ren. Knowledge of how sport fandom is developed and how families derive benefits from their customer-to-customer interaction (Uhrich, 2014) will assist managers in shaping marketing appeals in a way to increase repeat purchase, usage and loyalty (Funk \& James, 2001).

The remainder of this article is organized in the following way. The first section provides a brief overview of previous work on sport fandom. This is followed by consideration of the parenting and consumption as well as parenting and sport participation literature and the inter-relationships therein. Next, the empirical study is described and the typology of sport fandom and parenthood is presented. The fandom socialization activities and behaviors that emerged from the data are then examined. We conclude by discussing our findings, highlighting the managerial implications as well as exploring opportunities for further research.

\section{Literature review}

\section{Fandom}

Sport fandom has been attributed with compensating for what is lacking in modern day life (Bernthal et al., 2015; Jenson, 1992; Melnick, 1993). Researchers are interested in 
how fans co-create value and derive benefits from fandom through their interaction as well as the ways in which resources are integrated by multiple actors to co-create value (Vargo \& Lusch, 2016). In characterizing different types and levels of engagement with sport teams, previous researchers have examined a variety of typologies associated with fandom (Hunt et al., 1999; Tapp, 2004; Tapp \& Clowes, 2002) identifying how and in what ways fans can be valuable assets to the teams and athletes they support. However, as Woratschek et al. (2014, p. 9) note, 'previous research has not fully appreciated the role of the [sports fan] customer in the value-creation process.' Developing sport fandom at an early age will increase the lifetime value of a fan considerably. Understanding fans who 'dropout' (Mullin et al., 2007) and whether this is a temporary or fixed state will be beneficial to marketers concerned with rejuvenating sports fan loyalty or re-engaging with latent fans.

Although sport fandom can engender feelings of pride and social prestige, there has been a growing literature which focuses on the negative aspects of fandom including hooliganism and violence (See King, 2001). Additionally, Wann and Weaver (2009, p. 219) argue sport fandom can be 'negatively correlated with depression, alienation, and experiences of negative affect.' Furthermore there has been focus on what leads to withdrawal and 'deescalation' (Bernthal et al., 2015). For example, the notion of 'reflected failure' has caused fans to distance themselves from their team because of greedy players (Campbell, Aiken, \& Kent, 2004) poor team management of player scandals (Fink, Parker, Brett, \& Higgins, 2009), lack of team success (Wann et al., 1996), loss of star players (Bernthal et al., 2015) or can simply relate to geographical distance (Fairley \& Tyler, 2012) and/or peer disinterest (Hyatt \& Foster, 2015). However, there is a lack of research which explains how changes in everyday life circumstances impacts upon consumer behavior (Wells, 1993) and in the context of this research how a major change in family circumstance can potentially transform levels of fandom despite calls for further research in this area. Previous studies on reducing 
fandom in this context are scant and the extent to which this is a temporary withdrawal of allegiance has not been examined in depth or in a contemporary context.

\section{Parenthood, consumption and sport}

Previous studies on parenthood and consumption have been concerned with the cost of having children (e.g. Bradbury, 2008), how children learn to be consumers (e.g. John, 1999) and the extent to which materialism develops in childhood (e.g. Richins \& Chaplin, 2015). Invariably the way in which children are socialized as consumers is ascribed to parenting styles (Rose, 1999). The role of parents in socializing their children in consumer behavior and related practices is well documented (See for recent examples: Lawlor \& Prothero, 2011; Mau, Schramm-Klein, \& Reisch, 2014; van Reijmersdal, Lammers, Rozendaal, \& Buijzen, 2015; Watne, Brennan, \& Winchester, 2014) and has been considered in relation to purchase decision making, media exposure (and the relative effectiveness of such communication) as well as enrichment or extra-curricular activities (Vincent \& Ball, 2007) and changing family structure. Importantly while recent research has taken a broader view of individuals or groups socializing children in relation to their consumer behavior (Kerrane et al., 2015), there has been limited if any research on how parents socialize and/or co-create value by motivating their children through sport fandom related activities. As sport plays a central role in the socialization of children in the UK, with a particular emphasis on the commercially-oriented relationships children have with UK football clubs (Thomson \& Williams, 2014) examining the emergence of fandom in a sporting context will be illuminating. Thomson and Williams in their UK study also suggest children articulate a portfolio of teams of which they are fans in direct contrast to studies on adult sport fandom and these connections are said to be 'shaped by a complex web of influences including family and family history, friends, media and geography (2014, p. 323).' This too is worthy of further research. 
Researchers have considered the role of parents in the participation of sport activities and have discussed the notion of 'good' parenting in relation to active involvement in sport outside the home environment (Trussell \& Shaw, 2012). Wheeler and Green (2014) note that parents view encouraging their children to participate in sport-related activities as an 'investment' suggesting that such activities may be dependent on income as well as time/availability (Outley \& Floyd, 2002). This investment can be realized as studies have shown that the longevity of engaging in sports is dependent on how children have been socialized (Haycock \& Smith, 2014). This is important as it may have implications for understanding how value is co-created in a network (Vargo \& Lusch, 2016) as well as the longevity of sport fandom and how it is cultivated in childhood.

Dietz-Uhler and Lanter (2008) report that while females are more likely to be sports fans to spend time with family or friends, sport fandom for males is about the excitement or emotion associated with fandom. Tapp and Clowes (2002) observed in their study that 'Dads and sons' who attended football games were quiet fans and did not associate with a group. This suggests that parents who associate negative behaviors with sport fandom are more likely to be reluctant to socialize their children in this type of (consumer) environment. Similarly, parents using sport fandom as a means of 'escape' or diversion from home or family life (Sloan, 1989) will be less inclined to view consuming sport as a family activity. Wann (1997) observes that stressful or personally difficult times enhance the motivation for escape. How these motives and related consumer behaviors manifest during parenthood is under-researched.

\section{Method and data collection}

The aim of our empirical study ${ }^{1}$ is to explore the intersection of sport fandom and parenthood over time and the implications therein. First, this study was designed to establish

\footnotetext{
${ }^{1}$ Approval for the study was sought and granted by the University's Ethics Committee
} 
the type of sports fan the parent respondents represented in order to develop a typology of the (de)-escalation of sports fandom as it pertains to parenthood. Second, we explored the extent to which parents co-create value and socialize their children through sport fandom and the consequences for understanding if, how and in what ways fan loyalty is encouraged, ignored or rejected in children. The exploratory nature of these topics suggested a qualitative approach was likely to reveal the insights and depth required to meet the aim of the study. This approach followed similar studies that have attempted to develop an understanding of the (social) factors affecting consumer behavior with specific reference to sport fandom (e.g. Hyatt \& Foster, 2015; Uhrich, 2014). A narrative analysis is used here to gain comprehensive insight into the experiences of sports fans and the impact parenthood has had on their related consumer behavior. The data collection included a combination of methods and planned prompts (McCracken, 1988).

\section{Stage 1: In-depth interviews}

We conducted in-depth interviews with 15 fans of any sport that were also parents of children of any age (See Table 1) and encouraged them to make sense of their sport fandom through storytelling and narrating themselves in their own stories (See Linde, 1986). The participants were resident and recruited in central Scotland by asking colleagues for referrals. Subsequent sampling was managed through snowballing, previously used in sport research (Beedie, 2007). Interviews took place in Edinburgh, Glasgow and Stirling. Earlier participants were asked not to disclose details of the interview so as not to bias the research. Using the definitions outlined above (Hirt et al., 1992; Hunt et al., 1999) the participants were identified as sport fans as opposed to simply spectators. This initial phase of research was designed to understand the impact of parenthood on sport fandom per se and included those 
who were fans of cricket, golf, rugby, darts, showjumping and basketball as well as football. This offered a broad overview of the characteristics of parents that also identified as being a sports fan and provided a foundation for the second stage of research.

[Table 1 near here]

The in-depth interviews were in two parts. Initially, parents were asked to relate their first memories of being a sports fan (using prompts such as people who were there, sights/sounds/smells, nostalgia/how it differs to more recent experiences etc.) and how others would know they were a sports fan (e.g. affiliation with team/club, attendance/nonattendance, player specific fandom, membership, use of merchandise etc.). Stories associated with motivations and de-motivations for being a sports fan, including reflected failure (Campbell et al., 2004), were also explored. Additionally the interviews examined the extent to which sports fandom was an individual or family activity (and why) as well as social or temporal effects on being a fan. Periods of transition and their relative impact e.g. marriage, divorce, moving home etc. were also considered in relation to sports fan behavior. Discussion as well as reflection on transition events allowed the focus of the interview to move beyond sport fandom per se and to facilitate narratives on if, how and the extent to which, parenthood affected sport fandom.

In the second part of the interview, we were interested in the notion of the disruption associated with such a life event, whether there was withdrawal from fan related behavior, the extent to which this was temporary or complete, how this affected self and social identity, and what, if any, differences there were in values and attitudes towards sport participation of child/ren versus sport fandom. If, how and in what ways parents considered their child/ren were socialized in relation to sport fandom were also explored and included a reflection on the role of peers, school, media, sport/club community as well as the parent/s. How parents perceived the co-creation of value through sport fandom and the benefits derived from such 
network interaction was also examined. The interviews ranged from 45 to 65 minutes and the sample was purposive to ensure diversity amongst the respondents and responses.

\section{Stage 2: Online discussion group}

For the second stage of research we narrowed the context of our study. Research conducted by the Social Issues Research Centre (2008) illustrates that football fandom in particular plays a significant role in family life in the UK. Their findings indicate that football fandom facilitates day-to-day interactions within a family and that this sport especially becomes embedded in the history of families in the UK. Further as football is a multi-billion industry (Deloitte, 2015) and because of the global popularity of football (Turner, Barlow, \& Heathcote-Elliott, 2000) the audience interested in the outcomes of our study is extended. Thus, to further develop an understanding of the intersection of parenthood and sport fandom we employed an online forum to engage parents specifically in discussion about football fandom. An equal gender split of 20 parents from across the UK were recruited using the services of a market research agency to ensure a purposive sample (See Table 2). The online discussion was active across a week with new topics introduced daily to maintain interest as well as to ensure relevant data to develop the theoretic concepts and to build on interview data. Respondents could use private messaging to avoid publicly discussing personal or sensitive issues. Parents were asked to raise any issues in relation to football fandom that they considered to have to been overlooked to ensure a comprehensive data set for analysis. In total (including private messaging) there were over 300 posts.

[Table 2 near here]

\section{Data analysis}

The analysis of the data explored individual and shared behaviors, personal and family disruption as well as perceptions of allegiance and (dis) loyalty in the responses using the methods outlined by Strauss and Corbin (1990). Open, axial and selective coding was 
employed: (i) to examine the similarities and differences in the responses using the constant comparison method to question the phenomena reflected in the data, (ii) to give special attention to the context and interactions among actors on singular attributes and, (iii) to select the main story underlying the analysis. This interpretation was developed as a result of the relationship between emerging insights and prior assumptions (Spiggle, 1994). The authors brought different perspectives to the analysis and interpretation. All were involved in the design of the interviews and online discussion and each independently looked for commonality in interpretation through discussion.

\section{Findings}

In the initial section of findings we present four types of sports fan pertaining to the intersection of parenthood and fandom. These segments, which emerged from Stage 1 interview data, reflect the key characteristics that differentiate each parental sports fan type (See Table 3). For each grouping there are a number of salient issues, including fandom as a means of expressing a self and/or family identity, the extent to which parenthood impacts (de)-escalation of sport fandom activity and fandom as a means of co-creating value and deriving benefits from customer-to-customer interaction. The typology offered here is illustrative of types of parents that are also sports fans and their relative fandom characteristics. The four types of parent sports fans depicted here are Breathers, Begrudgers, Bonders and Balancers. Within the typology there is a divergence between self and social identity which will be examined in relation to parenthood and 'fandom socialization'. Following this, we further explore how these typologies intersect with parenthood with specific reference to football fandom. We do so by examining parental perceptions of the football environment, allegiance and disloyalty, individual and shared behaviors as well as temporal changes to sport fandom and the building of autobiographical memory.

[Table 3 near here] 


\section{Breathers: Sport fandom and escape}

'Breathers' are typically characterized as loyal and enduring in their sport fandom behavior. And, in a similar way to the wrestling fans described by Wann et al. (1996), Breathers focus on the way in which their sport fandom offers a release from family (and work) pressure. Their behaviors associated with sport fandom are not related to the cocreation of value with or the (consumer) socialization of their child/ren, rather they use this aspect of their leisure time to express a particular self-image that is detached from their parenting role. As Graeme explains:

If I was to go [to the game] with my children I'd have to be a lot more calmer as I would have to be an adult. When I go with friends I can be a lot more loud and shout at away fans.

Alec (See Table 3) is also typical of Breathers in describing how he is almost religious in his fandom behavior (Prebish, 1984). He keeps sacred his time to support his team and indicates that there would have to be significant reasons for his own non-attendance at a game.

While acknowledging the financial cost of being a fan is steadily increasing, Breathers often offer a rationale for this being the case. This reinforces the way in which Breathers can view their fandom as a valuable individual experience for which they are prepared (and expect others) to meet the necessary expense:

Many things have happened to my football team and the worst being placed in administration, liquidated and finally being placed in the lowest rung of the league ladder. As a football fan that scenario changed my whole attitude towards ticket pricing.... a true fan would pay, no question. (Colin)

Interestingly this segment is also the one most likely to acknowledge the way in which reflected failure can negatively impact their behavior. As Graeme notes (See Table 3) 
the undesirable emotions generated by the loss of a game can make him physically withdraw from social interaction. This is consistent with cutting-off-reflected failure (CORFing) to assist in the maintenance of self-esteem (Wann \& Branscombe, 1990). This degree of emotional engagement may explain the detachment from the parenting role as this image is not congruent with the responsibilities of being a mother or father. Breathers are also more likely to have an older demographic profile (See Colin, Tables 1 and 3) and demonstrate a traditional rather than egalitarian approach to parenting (Sabattini \& Leaper, 2004). This means parenting is likely to be more authoritative than permissive in such households and that fandom and related affiliation may be more gender specific (Aunola, Stattin \& Nurmi, 2000; Starrels, 1994).

\section{Begrudgers: Resentment and rejection}

Begrudgers reject what football fandom and associated practices can 'teach' their children. Louise (See Table 3) rejects the notion of socializing her children about football fandom as the examples offered by players (e.g. spitting, swearing) are not ones she wants them to learn. Similarly she resents that the 'obscene' amount of money paid to players can lead her children to think that, 'you don't have to work hard or behave well to make a fortune.' Williams (2006) observed the negative impact of conduct on the field as well as the commercialization and 'reinvention' of the sport and Begrudgers similarly recognize the sport as having fundamentally changed and not in a positive way. However, despite Louise's rejection of football fandom, her parenting role in customer-to-customer interaction is still evident at an intra-level (Woratschek et al., 2014) as Begrudgers co-create value by keeping their children from being exposed to what they perceive as negative aspects of the sport.

Begrudgers not only reject teaching their children to be football fans, but they also negate being a fan as part of their own identity. Brendan (See Table 3) notes that he is discerning and is not prepared to spend a significant sum to be a football fan. His self-identity 
is manifest in his non-consumption (Cherrier, 2009). Through his decision-making he is saying that being a contemporary football fan 'is not me' (Hogg \& Banister, 2001) and that this has evolved over time. His non-consumption makes a statement regarding how he views himself in this context (Hyatt \& Foster, 2015) and in order to protect his self-identity and self-esteem he avoids attendance of games. Begrudgers are also more nostalgic and consequently have a preference for past experiences (Holbrook \& Schindler, 1996).

\section{Bonders: A social approach to sport fandom and participation}

Bonders are the opposite of Breathers as rather than viewing their fandom as a form of 'escape', being a sports fan is nurtured within the family (Fitzgerald \& Kirk, 2009) and is used as a way to socialize children more generally. This segment is not characterized by fandom of a particular sport, rather their affiliations are more eclectic than other parent sport fandom types. As Darren suggests (See Table 3), engagement with sport affords an opportunity to reinforce family values and life skills. This supports Crawford (2004) who notes the importance of engaging as a sports fan is not necessarily about winning or losing but that rather it is the process of consumption which is important. For Bonders, participation in sporting activities is symbiotic with sport fandom where sport fandom encourages sport participation and vice versa. While previous studies have linked sports participation in childhood to sports participation in adulthood (Haycock \& Smith, 2014) researchers have yet to fully explore the relationship between sport fandom and sport participation in children. Bonders also approach sport fandom and participation as a way of co-creating value in a network (Vargo \& Lusch, 2016). For example, Joan (See Table 3) uses sport as a way to expand and enrich the social experiences of her children. This offers further reasons for how and in what ways parents are motivated to encourage their children to engage in sport-related activities (Duda, 1996) and how parents and their children derive benefits from such interaction (Uhrich, 2014). 
Interestingly Bonders are also more likely to admit altering their fandom behavior post-parenthood (See Michael, Table 3). Spectators are both co-producers and recipients of stadium atmosphere (Uhrich \& Benkenstein, 2010) and Michael reflects on and further underscores the importance of a social image and positive environment that is compatible with the parenthood 'role' when he considers 'what I should sing' and avoids swearing and confrontation after becoming a father. Contrary to Breathers, Bonders use reflected failure as a way in which to facilitate an understanding of winning/losing and Darren exemplifies the attitude of Bonders when he discusses fandom socialization:

You can get too emotional, you can let the game ruin your day. I think being a fan... you take the highs and lows, you have good days and bad days. I want my kids to deal with the bad days in a good way. I want them to say, look we played well but we lost. We are going to win next time!

Bonders in our sample were also the segment most likely to have lived in a variety of countries, towns and cities across UK and Europe. In a similar way to the children described in Thomson and Williams' (2014) UK study on football fandom, Bonders have a 'portfolio' of teams that they have a connection to which directly contrasts with other studies on adult sport fandom. This eclectic approach to sport fandom may be as a consequence of access to a variety of sporting communities that has similarly been reported by Waters, Burke, Jackson, and Buning (2011).

\section{Balancers: Sport fandom is a risky business}

While Balancers are somewhat similar to Bonders in that they encourage their children to participate in sport, their concerns regarding the risks associated with sport fandom are less likely to be shared with Bonders. Bonders use negative sporting behavior as a way to educate their children on how not to behave but Balancers do not want to risk putting 
their family in that position at all as rationalized by Ivan. In doing so, opportunities for the children to co-create value within such a network is reduced:

I remember thinking about taking the kids to a friendly charity match. We went but in the end they didn't as they had something else on. While [the charity match] was good fun, even at the friendly there was some choice language and rough behavior by fans who didn't show respect for any of the kids around them - and it was a friendly! I think die-hards should realize their behavior can color the love of the game for the next generation in a negative way if families have to stay away for safety reasons with all the jostling.

Balancers as a parent sport fan type are more likely than any other segment to identify as a fan with a variety of diverse sporting activities (See for example John, Table 1). Similarly Balancers could not be described as 'die-hard' fans (Wann \& Branscombe, 1990) as their fandom behaviors were generally limited to engagement if their team was performing well. For Balancers, the emotional significance and value derived from engaging in sport fandom behavior (Hirt et al., 1992) appeared to be superseded by the onset of parenthood. The parenting role for Balancers was synonymous with personal sacrifice and an emphasis on the needs of their children (Simon, 2008). While Balancers are likely to retain an interest in their sport fandom (See Marion, Table 3) aspects of their perceived parenthood role, including encouraging their children to participate in sport with focus on their social development, meant the importance placed on their own sport fandom was limited.

This typology illustrates that parents can either use their sport fandom to detach from or reinforce their parenting role. Breathers in particular reveal that their sport fandom is incongruent with the expected behaviors of 'adults' and that their emotional engagement and related outcomes are not compatible with that of a nurturing role. The complete opposite is evident in the characteristics of Bonders. Bonders judge their sport fandom as an opportunity 
to educate as well as instill family attitudes towards life and derive benefits from value cocreation. They perceive sport fandom and participation in sporting activities as inter-related and emphasize a social rather than a self-identity. Begrudgers ignore or reject sport fandom in their children and as part of their self-identify as a consequence of perceived changes to the sporting environment, while Balancers are particularly concerned to meet their parenting role and this can lead them to minimize their previous interests. To further develop an understanding of the intersection of parenthood and sport fandom an online study was conducted with football fan parents only. This was to narrow the focus of the study as well as to consider and further understand emergent themes and issues in relation to the topic under consideration. These themes also serve to explore the typologies further.

\section{The football environment: A place for children?}

In explaining the impact parenthood had on their football fandom behavior, parents often discussed how their concerns regarding the football environment had increased significantly. Broadly they worried about what their children would learn from the football environment and, in particular, the commercialization that is evident in the game. Their concerns centered on how their children would perceive the increasingly corporate nature of football clubs, gambling and match fixing as well as the payment of players (and consequently the types of players that were attracted to football clubs). Importantly for parents this environment was not always one that they wanted to expose their children to or for their children to learn from although as football fans they were cognizant that for the game to thrive, generating interest amongst their children was essential for the long-term future of the sport. In this way there is recognition that value is co-created through live sporting occasions.

Barbara exemplifies the view of a Begrudger in explaining how the commercialization of football clubs has had an impact on the game and is potentially 
changing the nature of football fandom for future generations. She explains why she rejects football fandom as part of her self-identity and why she does not cultivate football fandom in her children:

Now managers don't last two minutes and players are not even home grown. It's steadily moved away from the sense of community, locality or region and if anything become global and more about the corporate world...it's not how it used to be...it's not how I remember it... being a part of something. I just don't buy into it now. Interestingly Gordon who, as a Bonder, acknowledges the social well-being afforded by football fandom observes that even if there is a desire to engage children in such activities and derive the benefits from co-creating value,

the cost of tickets to any Premiership game today, make it practically impossible to go to see your favorite team...because the players and managers are all paid far too much money which we have to pay quite a bit towards in the end...so I can't [take the children to football games] even though I want to.

Similarly Gemma notes that while she too has the characteristics of a Bonder that the poor behavior of players is more problematic for her since she became a parent:

I am very easily incensed by poor sportsmanship on the pitch and bad behaviour off it. Footballers (especially Premiership) are paid (I will not say earn!) exorbitant amounts of money and sponsorship and as such MUST recognise that they have a responsibility to behave in an exemplary manner at all times. I do not appreciate having to explain to my (then) 5-year-old daughter about the ins and outs of 'date rape' because of them!

These concerns contribute further to both our understanding of reflected failure as well as why parents may choose not to cultivate football fandom in children. However, it is not only the behavior of the players that causes apprehension but also other fans. Despite 
football fandom offering the opportunity to socially connect with others (Bernthal et al., 2015) parents consistently cite other fans as a deterrent to engaging their children in football fandom activities. Lucy, as a Balancer, is acutely aware of the risks in the stands:

Some games I would never take my child too - especially if I know there is going to be trouble or the game has had trouble in past fixtures. I don't like the racist chants, swearing, etc.... It's still there even though they have tried to stamp it out... I just don't like the kids hearing it.

While displaying a similar position to Louise, a Begrudger (See Table 3) Lucy differs in her view from Louise as she is prepared to take her children to football games and because her focus is on the immediate safety of her children. Louise, in comparison, rejects attendance at games and emphasizes the poor example of the players rather than the fans.

\section{Allegiance and disloyalty}

Despite the football fandom environment often being a challenging one it does offer parents the opportunity to share their emotional engagement with their children. This is particularly evident when children support the same team as their parents as Gordon explains: 'I am pleased that I can share my enjoyment, excitement and more recently disappointment with my younger son at least.' This also reinforces the ecosystem of value co-creation where the focal actors (club and parent) need resources from other stakeholders (children) to cocreate value (Woratschek et al, 2014). For parents with younger children, there is a hope and/or expectation that the child/ren will support the same team as the parents although this becomes more problematic when the parents support different teams. In this sample, it is the mothers, like Anna who are more likely to acquiesce and recognize the bonding opportunity football fandom may afford her husband and son:

I think my husband would really love it if he were to follow him and support Liverpool...I only worry that he may support Man United like me, which would 
horrify my husband as a Liverpool fan! I'm not fussed either way, I like to let him choose his own interests.

This underscores the assertion that masculinity is still a prominent aspect of the profile of a football fan (Porat, 2010). When interest in football is not shared by their children, parents can illustrate disappointment as well as reflect on their own ability to socialize their children in sport fandom behavior. As James explains, despite his attempts to be a 'Bonder' his attempts at imparting the significance of football to his two boys have been met with disinterest by them and disappointment by him. As a consequence, James exhibits the characteristics of Breather using football to escape and it may be that the type of parent sport fan is affected by the attitudes and behaviors of their child/ren:

To be perfectly honest neither of my two boys showed any great interest in football but it wasn't for the lack of trying on my part as I frequently took one or both with me on a match day. It soon became quite apparent that they would rather excuse themselves to go to the toilet only to be found running up and down the length of the concourse chasing each other.

However, disinterest in football fandom has less potential for conflict in families than when children are considered to be disloyal by supporting a different football team to their parents. Amanda explains that while her father was her motivation for being a football fan, her choice of team has caused (on-going) friction between them as she is considered 'disloyal' for choosing to support a Premier League side:

Quite frankly my Dad was my motivation for being a football fan [he supports Brighton and Hove]...Much to my Dad's horror I subsequently supported Man United and in the 90's moved to Manchester as I had a season ticket. He was so grumpy at first [when I started to support Manchester United] as he thought I was so disloyal. If I remember correctly he didn't talk to me for a couple of days...I'd like to say that 
we're all grown up about it now but when it comes to football, supporters do tend to turn into children.

This familial conflict may also partly explain Amanda's categorization as a Breather. However, the roles adopted by the father and daughter described above is opposite to that expressed by George. It can be seen here that while football fandom can cause division in families (Porat, 2010) it can also be used to bond as well as build autobiographical memories (Nelson \& Fivush, 2004) for both parents and children:

Now my kids are old enough to go and enjoy the match I wouldn't never not have them with me. I love seeing their faces light up when we score and how excited they get. It reminds me of myself when I was young and that's so special I wouldn't want to miss that.

This further illustrates bonding and detaching which builds on the initial parent sport fan typology depicted here and is similar to research studies on how consumption experiences more broadly can connect or disconnect children and their parents (Coakley, 2006). It also shows the benefits derived from customer-to-customer interaction (Uhrich, 2014) as well as how the value of sports events are co-created in a collaborative process (Vargo \& Lusch, 2016).

\section{Temporal effect of parenthood on football fandom}

The premise of this study was ultimately to examine how and in what ways there was a (de)escalation of sport fandom as a consequence of parenthood (Hyatt \& Foster, 2015). In addition to the typology described above, this study shows that parenthood can cause deescalation of fandom, and while this can be temporary, new responsibilities often mean that previous levels of engagement are never fully recovered. Laurence is representative of Balancers who, in meeting their own expectations of their parenting role, de-escalate their own fandom behaviors: 
For me having children did have an impact on being a fan, I went to less games mainly due to new commitments and priorities. When the children were old enough I then enjoyed going to games as a family but don't go as often as I used to.

However Patrick illustrates that there is some evidence of a (de)-escalation cycle.

That is, while a Bonder can use football fandom as a way in which to socialize their child/ren, when their children are grown up the parent/s can resume their previous football fandom activities as a Breather:

I have been a Chelsea season ticket holder for 35 years. When my son started to show proper interest I got family season ticket for a couple of years. My son now plays footie at weekends so can't go with me so I've gone back to games with the lads. Parents also adopted strategies to maintain their emotional attachment to their team while meeting their parenting roles as explained by Balancer, Maureen:

Kids get in the way a little. Not that I begrudge having them but why is it that gym/trampolining/athletics competitions normally clash with the match? I watch as many as I can live but will record matches that I'm out of the house for. Smartphones come into their own for following the scores when you're out too!

This illustrates the continuing importance of the social and experiential nature of sport fandom (Wann \& Weaver, 2009) despite the onset of parenthood, suggesting social wellbeing is still sought through sport fandom behaviors regardless of such a transition.

Finally there was further evidence amongst the football fandom respondents that sport fandom and sport participation were inter-related as Ralph suggests here: 'Following a football team motivates my eldest to play football for the primary school team and he seems to get some of his inspiration as a result of following football in real life.' This has implications for those interested in encouraging sports participation as, in this study, parents 
typically agree that there is a symbiotic relationship between sport fandom and the playing of sport.

\section{Discussion/Conclusion}

Drawing on extant studies of sport fandom and building on the work of Hyatt and Foster (2015) this research examines the intersection of parenthood over time on the (de)escalation of engagement with sport fandom. Our study focuses on how parenthood differentially impacts on individual and social behaviors and has important implications for our understanding of the way in which 'fandom socialization' occurs. The findings of a wide ranging number of past studies indicate that sport fandom can facilitate well-being and social integration as well as engender reflected failure. However, a comprehensive analysis of the impact of parenthood on sport fandom behavior and sport socialization has previously been overlooked.

This study contributes to the literature in a variety of significant ways. Importantly, our research offers the first comprehensive exploration of how and in what ways becoming a parent and raising child/ren impacts on consumer behavior in a sport fandom context. Based on the findings from our initial qualitative study, we develop a typology of parent sport fan types using commitment to fandom activities and engagement with family in fandom and sport-related activities. This typology allows us to categorize those parents most likely to socialize their child/ren in sport fandom behaviors and therefore builds on prior studies that are concerned with the consumer socialization of children and sport fandom behaviors. This typology is a categorization of characteristics associated with changes to sport fandom behavior as a consequence of parenthood. In addition to identifying attitudes and behaviors of parents in relation to their fandom behavior, we also explore the extent to which there is a perceived link between sport fandom and sport participation in children. This study has also started to explore value co-creation and the benefits derived from customer-to-customer 
interactions in the context of parenthood and the fandom socialization of children. This collaborative process has previously been overlooked in sports management theory.

Our second stage of research, focusing purely on football, reveals three key emergent themes that capture in greater depth why parents choose to cultivate, ignore or reject sport fandom in their children: (i) The Football Environment: A Place for Children? (ii) Allegiance and Disloyalty and (iii) The Temporal Effect of Parenthood on Football Fandom. The identification of these topics provide insight into the specific behaviors of parents who are also football fans and explain how different factors including excess and moderation, individual and shared behaviors as well as parental sacrifice (Simon, 2008) contribute to a parent's willingness to socialize their children in fandom-related behaviors. This study contributes to our understanding of how attitudes towards sport fandom are formed. In this way, the study not only addresses calls in the literature to examine the intersection of parenthood and sport fandom behavior (Hyatt \& Foster, 2015) but also reflects on the longerterm consequences of a life altering transition on consumer behavior (Wells, 1993). Importantly our emergent themes develop an understanding of the initial characteristics identified in the typology. Thus our research offers a comprehensive analysis of fandom socialization and extends previous literature which has had a limited focus on parents and their efforts to engage children in sports activities.

In the context of socializing children as consumers, this study offers several emerging viewpoints. First, parents perceived level of risk associated with sport fandom will determine whether fandom socialization is cultivated, ignored or rejected in children. Second, there would appear to be a link between engagement in sporting activities and sport fandom. Third, our findings provide support for the idea that parents can use their sport fandom to detach from the family as well as bond with their child/ren (sometimes differentially) and this can be shaped by the perceived 'disloyalty' or 'disinterest' shown by child/ren. Fourth, sport fandom 
and related events can be viewed as platforms where different actors (e.g. parents and their child/ren) spend their leisure activities co-creating value within a network. Fifth, there is genuine concern that the football industry is not contributing towards fandom socialization. To facilitate the value co-created by fans and their families grassroots support should be recognized as significant to the future of the game.

On a more expansive level, this study has shown that parents can view their sport fandom as a way in which to socialize their children more broadly. This includes helping children to understand what is it to win/lose, how to manage disappointment, what it is to be 'loyal' and how to respect rules associated with sport. Similarly how sport fandom can facilitate social ties and social networking has been underscored here. Thus the importance of fandom socialization is quite different to the materialism associated with consumer socialization.

\section{Limitations and future research}

As this study is unique there are a number of opportunities for future research that could extend the initial findings posited here. While our study incorporated views from both mothers and fathers who were sports fans as well those representing a variety of sports, football fandom was underscored. As different sports may attract a variety of fans, a study that draws a comparison between sport fandom in parenthood and different sports (excluding football) could provide additional insights to the characteristics detailed in our typology. Similarly, while we provided a longitudinal view of the intersection of parenthood and fandom through our sampling approach, a study that considered sport fandom at time ordered regular intervals with parents and their children may develop a deeper understanding of the temporal effects of parenthood on such behaviors. This study was also conducted in a singular context (i.e., United Kingdom). Sport fandom and its association with parenthood may manifest itself differently in other contexts or cultures around the globe. 
Lastly, although a qualitative methodology allowed us to meet our research objectives, there is scope to develop a quantitative study on the link between sport fandom and sport participation in childhood. It would be interesting to investigate how widespread such practices are as well as the long-term impact on consumer loyalty and buyer behavior. A quantitative analysis may also demonstrate ways in which to encourage sport participation through sport fandom. As the focus of this study was parenthood, considering the role of sport fandom from the perspective of children may also reveal insights to encourage youth sports participation.

\section{Managerial implications}

This study contributes not only from a theoretic perspective but also has implications for engaging sports fans through loyalty schemes and marketing packages. It is clear in this study that being a parent and sports fan does not always involve actual attendance at sporting events because of the cost of a ticket/s or the perceived unsuitable nature of the environment. Consequently, fostering a sense of community and facilitating a loyal fan base of parents and their children outside of the stadium requires a 'third place' to emulate the positive aspects of the social climate and environment experienced in the sports ground (Fairley \& Tyler, 2012). While traditionally this third place would be a pub or bar (Weed, 2007) importantly from a marketing perspective, increasing the number and diversity of locations to allow fans and their families to engage with sport will be more likely to attract a varied group of consumers and their limited disposable income. As coffee culture continues to grow (Tucker, 2011) there may be scope for the 'third place' in relation to sport fandom activities to be associated with and/or in partnership with specific coffee outlets. This would offer a familiar and 'safe' environment for sport fan families as well as encouraging sponsorship and joint venture opportunities to event organizers and coffee houses. As the marketplace now offers more assorted and abundant opportunities to engage in fan related activities, the challenge for 
marketers is to involve sports fan event attendees and non-attendees in the same way (Dwyer \& Drayer, 2010).

While season tickets are one measure of loyalty, our typology illustrates that different groups of sports fans will be attracted to sport fandom in different ways. To that end, specific strategies can be used for the different categories of the typology presented here. For example, marketing managers could focus on re-engaging Begrudgers through emphasizing nostalgia in their communication messages and recognizing the need to establish value for money. If this group does not attend the actual sport event/s, they may be encouraged by opportunities to access groups or communities of like-minded supporters in alternative venue/s. Marketers can appeal to Bonders by creating particular family packages that highlight the social aspects of sport fandom and the educational potential of engaging in such behaviors. The use of social media to promote family fandom activities and to create online 'space' to share images and narratives of sport fandom events would enhance the notion of sociability and co-creating value through deriving benefits from customer-to-customer interaction that is important to this group. Loyalty packages could be structured to attract different types of parent sports fans to attend a variety of events. For example bronze, silver and gold family packages could be made available to cater for income and spend decisions. Event organizers need to think carefully about mediating risk factors if the Balancers are to be engaged in sport fandom activities. Finally, while Breathers may never involve their family in their sport fandom activities, special 'one-off' family events may encourage intermittent family engagement which could lead to longer-term interest in sport in children.

Conflict of interest: The authors have no conflicts of interest to declare. 


\section{References}

Aunola, K., Stattin, H., \& Nurmi, J.-E. (2000). Parenting styles and adolescents' achievement strategies. Journal of Adolescence, 23, 205-222. doi:10.1006/jado.2000.0308

Beedie, C. J. (2007). Placebo effects in competitive sport: Qualitative data. Journal of Sports Science and Medicine, 6, 21-28. doi:10.1123/ijsnem.17.3.259

Bernthal, M. J., Koesters, T., Ballouli, K., \& Brown, M. T. (2015). Motivations and fan engagement related to professional bass fishing spectatorship. Sport Marketing Quarterly, 24, 6-18.

Bradbury, B. (2008). Time and the cost of children. Review of Income and Wealth, 54, 305323. doi:10.1111/j.1475-4991.2008.00277.x

Branscombe, N. R., \& Wann, D. L. (1991). The positive social and self concept consequences of sports team identification. Journal of Sport \& Social Issues, 15, 115-127. doi:10.1177/019372359101500202

Campbell Jr, R. M., Aiken, D., \& Kent, A. (2004). Beyond BIRGing and CORFing: Continuing the exploration of fan behavior. Sport Marketing Quarterly, 13, 151.

Cherrier, H. (2009). Anti-consumption discourses and consumer-resistant identities. Journal of Business Research, 62, 181-190. doi:10.1016/j.jbusres.2008.01.025

Coakley, J. (2006). The good father: Parental expectations and youth sports. Leisure Studies, 25, 153-163. doi:10.1080/02614360500467735

Crawford, G. (2004). Consuming sport: Fans, sport and culture. International Journal of Sports Marketing and Sponsorship, 6, 47-62. doi:10.1108/ijsms-06-02-2004-b007

Deloitte. (2015). Annual review of football finance. Retrieved from http://www2.deloitte.com/uk/en/pages/sports-business-group/articles/annual-reviewof-football-finance.html

Dietz-Uhler, B., \& Lanter, J. R. (2008). The consequences of sports fan identification. In L. 
W. Hugenberg, P. M. Haridakis, \& A. C. Earnheardt (Eds.), Sports mania: Essays on fandom and the media in the 21 st century. Jefferson, NC: McFarland \& Company.

Duda, J. L. (1996). Maximizing motivation in sport and physical education among children and adolescents: The case for greater task involvement. Quest, 48, 290-302. doi:10.1080/00336297.1996.10484198

Dwyer, B., \& Drayer, J. (2010). Fantasy sport consumer segmentation: An investigation into the differing consumption modes of fantasy football participants. Sport Marketing Quarterly, 19, 207-216.

Fairley, S., \& Tyler, B. D. (2012). Bringing baseball to the big screen: Building sense of community outside of the ballpark. Journal of Sport Management, 26, 258-270. doi:10.1123/jsm.26.3.258

Fink, J. S., Parker, H. M., Brett, M., \& Higgins, J. (2009). Off-field behavior of athletes and team identification: Using social identity theory and balance theory to explain fan reactions. Journal of Sport Management, 23, 142-155. doi:10.1123/jsm.23.2.142

Fitzgerald, H., \& Kirk, D. (2009). Identity work: Young disabled people, family and sport. Leisure Studies, 28, 469-488. doi:10.1080/02614360903078659

Funk, D. C., \& James, J. (2001). The psychological continuum model: A conceptual framework for understanding an individual's psychological connection to sport. Sport Management Review, 4, 119-150. doi:10.1016/s1441-3523(01)70072-1

Haycock, D., \& Smith, A. (2014). A family affair? Exploring the influence of childhood sport socialisation on young adults' leisure-sport careers in north-west England. Leisure Studies, 33, 285-304. doi:10.1080/02614367.2012.715181

Heere, B., \& James, J. D. (2007). Stepping outside the lines: Developing a multi-dimensional team identity scale based on social identity theory. Sport Management Review, 10, 65-91. doi:10.1016/s1441-3523(07)70004-9 
Hirt, E. R., Zillmann, D., Erickson, G. A., \& Kennedy, C. (1992). Costs and benefits of allegiance: Changes in fans' self-ascribed competencies after team victory versus defeat. Journal of Personality and Social Psychology, 63, 724-738. doi:10.1037/0022-3514.63.5.724

Hogg, M. K., \& Banister, E. N. (2001). Dislikes, distastes and the undesired self: Conceptualising and exploring the role of the undesired end state in consumer experience. Journal of Marketing Management, 17, 73-104. doi:10.1362/0267257012571447

Hogg, M. K., \& Michell, P. C. N. (1996). Identity, self and consumption: A conceptual framework. Journal of Marketing Management, 12, 629-644. doi:10.1080/0267257x.1996.9964441

Holbrook, M. B., \& Schindler, R. M. (1996). Market segmentation based on age and attitude toward the past: Concepts, methods, and findings concerning nostalgic influences on customer tastes. Journal of Business Research, 37, 27-39. doi:10.1016/01482963(96)00023-9

Hunt, K. A., Bristol, T., \& Bashaw, R. E. (1999). A conceptual approach to classifying sports fans. Journal of Services Marketing, 13, 439-452. doi:10.1108/08876049910298720

Hyatt, C. G., \& Foster, W. M. (2015). Using identity work theory to understand the deescalation of fandom: A study of former fans of national hockey league teams. Journal of Sport Management, 29, 443-460. doi:10.1123/jsm.2013-0327

Jenson, J. (1992). Fandom as pathology: The consequences of characterization. In L. A. Lewis (Ed.), The adoring audience: Fan culture and popular media (pp. 9-29). Abingdon, VA: Routledge.

John, D. R. (1999). Consumer socialization of children: A retrospective look at twenty-five years of research. Journal of Consumer Research, 26, 183-213. doi:10.1086/209559 
Kay, T. (2006). Where's dad? Fatherhood in leisure studies. Leisure Studies, 25, 133-152. doi:10.1080/02614360500467792

Kerrane, B., Bettany, S. M., \& Kerrane, K. (2015). Siblings as socialization agents: Exploring the role of 'sibship' in the consumer socialization of children. European Journal of Marketing, 49, 713-735. doi:10.1108/ejm-06-2013-0296

King, A. (2001). Violent pasts: Collective memory and football hooliganism. Sociological Review, 49, 568-585. doi:10.1111/1467-954x.00348

Klein, M. (1990). The macho world of sport -- a forgotten realm? Some introductory remarks. International Review for the Sociology of Sport, 25, 175-184. doi:10.1177/101269029002500301

Lawlor, M.-A., \& Prothero, A. (2011). Pester power - A battle of wills between children and their parents. Journal of Marketing Management, 27, 561-581. doi:10.1080/0267257x.2010.495281

Harrington, C. L., \& Bielby, D. D. (2010). A life course perspective on fandom. International Journal of Cultural Studies, 13, 429-450. doi:10.1177/1367877910372702

Levine, M., Prosser, A., Evans, D., \& Reicher, S. (2005). Identity and emergency intervention: How social group membership and inclusiveness of group boundaries shape helping behavior. Personality and Social Psychology Bulletin, 31, 443-453. doi:10.1177/0146167204271651

Linde, C. (1986). Private stories in public discourse. Poetics, 15, 183-202. doi:10.1016/0304$422 \times(86) 90039-2$

Mau, G., Schramm-Klein, H., \& Reisch, L. (2014). Consumer socialization, buying decisions, and consumer behaviour in children: Introduction to the special issue. Journal of Consumer Policy, 37, 155-160. doi:10.1007/s10603-014-9258-0

McCracken, G. (1988). The long interview (Vol. 13). Thousand Oaks, CA: SAGE 
Publications.

Melnick, M. J. (1993). Searching for sociability in the stands: A theory of sports spectating. Journal of Sport Management, 7, 44-60. doi:10.1123/jsm.7.1.44

Mullin, B. J., Hardy, S., \& Sutton, W. A. (2007). Sport marketing (3rd ed.). Champaign, IL: Human Kinetics Publishing House.

Nelson, K., \& Fivush, R. (2004). The emergence of autobiographical memory: A social cultural developmental theory. Psychological Review, 111, 486-511. doi:10.1037/0033-295x.111.2.486

Outley, C. W., \& Floyd, M. F. (2002). The home they live in: Inner city children's views on the influence of parenting strategies on their leisure behavior. Leisure Sciences, 24, 161-179. doi:10.1080/01490400252900130

Porat, A. B. (2010). Football fandom: A bounded identification. Soccer \& Society, 11, 277290. doi:10.1080/14660971003619594

Prebish, C. S. (1984). "Heavenly father, divine goalie": Sport and religion. The Antioch Review, 42, 306-318. doi:10.2307/4611365

Richins, M. L., \& Chaplin, L. N. (2015). Material parenting: How the use of goods in parenting fosters materialism in the next generation. Journal of Consumer Research, 41, 1333-1357. doi:10.1086/680087

Rose, G. M. (1999). Consumer socialization, parental style, and developmental timetables in the United States and Japan. Journal of Marketing, 63, 105-119. doi:10.2307/1251778

Sabattini, L., \& Leaper, C. (2004). The relation between mothers' and fathers' parenting styles and their division of labor in the home: Young adults' retrospective reports. Sex Roles, 50, 217-225. doi:10.1023/b:sers.0000015553.82390.f7

Simon, R. W. (2008). The joys of parenthood, reconsidered. Contexts, 7, 40-45. 
doi:10.1525/ctx.2008.7.2.40

Sloan, L. R. (1989). The motives of sports fans. In J. H. Goldstein (Ed.), Sports, games, and play: social and psychological viewpoints (Vol. 2). New York, NY: Psychology Press.

Social Issues Research Centre. (2008). Retrieved from http://www.sirc.org/football/football_passions.pdf (accessed 15.06.16)

Spiggle, S. (1994). Analysis and interpretation of qualitative data in consumer research. Journal of Consumer Research, 21, 491-503. doi:10.1086/209413

Starrels, M. E. (1994). Gender differences in parent-child relations. Journal of Family Issues, 15, 148-165. doi:10.1177/019251394015001007

Strauss, A., \& Corbin, J. M. (1990). Basics of qualitative research: Grounded theory procedures and techniques (Vol. 15). Newbury Park, CA: SAGE Publications.

Tajfel, H. (1979). Individuals and groups in social psychology. British Journal of Social and Clinical Psychology, 18, 183-190. doi:10.1111/j.2044-8260.1979.tb00324.x

Tapp, A. (2004). The loyalty of football fans - We'll support you evermore? Journal of Database Marketing \& Customer Strategy Management, 11, 203-215. doi:10.1057/palgrave.dbm.3240221

Tapp, A., \& Clowes, J. (2002). From “carefree casuals" to "professional wanderers". European Journal of Marketing, 36, 1248-1269. doi:10.1108/03090560210445164

Thomson, E., \& Williams, R. (2014). Children as football fans: An exploratory study of team and player connections. Young Consumers, 15, 323-341. doi:10.1108/yc-09-201300394

Trussell, D. E., \& Shaw, S. M. (2012). Organized youth sport and parenting in public and private spaces. Leisure Sciences, 34, 377-394. doi:10.1080/01490400.2012.714699 Tucker, C. M. (2011). Coffee culture: Local experiences, global connections. New York, NY: 
Routledge.

Turner, A. P., Barlow, J. H., \& Heathcote-Elliott, C. (2000). Long term health impact of playing professional football in the United Kingdom. British Journal of Sports Medicine, 34, 332-336. doi:10.1136/bjsm.34.5.332

Uhrich, S. (2014). Exploring customer-to-customer value co-creation platforms and practices in team sports. European Sport Management Quarterly, 14, 25-49. doi:10.1080/16184742.2013.865248

Uhrich, S., \& Benkenstein, M. (2010). Sport stadium atmosphere: Formative and reflective indicators for operationalizing the construct. Journal of Sport Management, 24, 211237. doi:10.1123/jsm.24.2.211

van Reijmersdal, E. A., Lammers, N., Rozendaal, E., \& Buijzen, M. (2015). Disclosing the persuasive nature of advergames: Moderation effects of mood on brand responses via persuasion knowledge. International Journal of Advertising, 34, 70-84. doi:10.1080/02650487.2014.993795

Vargo, S. L., \& Lusch, R. F. (2015). Institutions and axioms: An extension and update of service-dominant logic. Journal of the Academy of Marketing Science, 44, 5-23. doi:10.1007/s11747-015-0456-3

Vincent, C., \& Ball, S. J. (2007). 'Making up' the middle-class child: Families, activities and class dispositions. Sociology, 41, 1061-1077. doi:10.1177/0038038507082315

Wann, D. L. (1997). Sport psychology. Upper Saddle River, NJ: Prentice Hall.

Wann, D. L. (2006). Understanding the positive social psychological benefits of sport team identification: The team identification-social psychological health model. Group Dynamics: Theory, Research, and Practice, 10, 272-296. doi:10.1037/10892699.10.4.272

Wann, D. L., \& Branscombe, N. R. (1990). Die-hard and fair-weather fans: Effects of 
identification on BIRGing and CORFing tendencies. Journal of Sport \& Social Issues, 14, 103-117. doi:10.1177/019372359001400203

Wann, D. L., Tucker, K. B., \& Schrader, M. P. (1996). An exploeatory examination of the factors influencing the origination, continuation, and cessation of identification with sports teams. Perceptual and Motor Skills, 82, 995-1001.

doi:10.2466/pms.1996.82.3.995

Wann, D. L., \& Weaver, S. (2009). Understanding the relationship between sport team identification and dimensions of social well-being. North American Journal of Psychology, 11, 219-230.

Ward, S. (1974). Consumer Socialization. Journal of Consumer Research, 1, 1-14. doi:10.1086/208584

Waters, R. D., Burke, K. A., Jackson, Z. H., \& Buning, J. D. (2011). Using stewardship to cultivate fandom online: Comparing how national football league teams use their web sites and Facebook to engage their fans. International Journal of Sport Communication, 4, 163-177. doi:10.1123/ijsc.4.2.163

Watne, T. A., Brennan, L., \& Winchester, T. M. (2014). Consumer socialization agency: Implications for family decision-making about holidays. Journal of Travel \& Tourism Marketing, 31, 681-696. doi:10.1080/10548408.2014.884966

Weed, M. (2007). The pub as a virtual football fandom venue: An alternative to 'being there'? Soccer \& Society, 8, 399-414. doi:10.1080/14660970701224665

Wells, W. D. (1993). Discovery-oriented consumer research. Journal of Consumer Research, 19, 489-504. doi:10.1086/209318

Wheeler, S. (2012). The significance of family culture for sports participation. International Review for the Sociology of Sport, 47, 235-252. doi:10.1177/1012690211403196

Wheeler, S., \& Green, K. (2014). Parenting in relation to children's sports participation: 
Generational changes and potential implications. Leisure Studies, 33, 267-284. doi:10.1080/02614367.2012.707227

Williams, J. (2006). 'Protect me from what I want': Football fandom, celebrity cultures and 'new' football in England. Soccer \& Society, 7, 96-114. doi:10.1080/14660970500355637

Woratschek, H., Horbel, C., \& Popp, B. (2014). The sport value framework - a new fundamental logic for analyses in sport management. European Sport Management Quarterly, 14, 6-24. doi:10.1080/16184742.2013.865776

Wisenblit, J. Z., Priluck, R., \& Pirog, S. F. (2013). The influence of parental styles on children's consumption. Journal of Consumer Marketing, 30, 320-327. doi:10.1108/jcm-02-2013-0465 


\section{Tables}

Table 1

Stage 1: Sample demographics and typology

\begin{tabular}{lcccccc}
\hline Pseudonym & Gender & Age & Occupation & Ages of children & Marital status & \multicolumn{2}{c}{ Sport/s of which parent is a } \\
fan & Typology \\
\hline Alec & Male & 52 & Armed Forces & 22 & Separated & Football \\
Colin & Male & 58 & Retailer & $23 \& 25$ & Separated & Football \\
Peter & Male & 38 & Entrepreneur & $3 \& 6$ & Married & Cricket/Rugby \\
Graeme & Male & 62 & Retired GP & $28 \& 30$ & Separated & Football \\
Louise & Female & 50 & Nutritionist & $12 \& 15$ & Divorced & Football \\
Paul & Male & 37 & Design Engineer & 9 months & Living with partner & Football \\
Brendan & Male & 49 & Teacher & $12,13 \& 15$ & Married & Beather \\
Darren & Male & 42 & Educator & $9 \& 4$ & Married & Begrudger \\
Joan & Female & 43 & Administrator & $12 \& 21$ & Married & Rugby \\
Yvonne & Female & 35 & Civil servant & 3 & Married & Show jumping \\
Michael & Male & 40 & Civil servant & $6 \& 8$ & Living with partner & Basketball/Football \\
Dave & Male & 55 & Educator & $19 \& 22$ & Married & Bonder \\
Ivan & Male & 57 & Electrician & 17 & Married & Bonder \\
Marion & Female & 31 & Customer service & 9 months & Married & Golf/Football/Darts \\
John & Male & 42 & Educator & 13 (twins) \&19 & Married & Balancer \\
\hline
\end{tabular}


Table 2

Stage 2: Sample demographics and typology

\begin{tabular}{|c|c|c|c|c|c|c|c|}
\hline Pseudonym & Gender & Age & Location & Ages of children & Marital status & $\begin{array}{l}\text { Sport/s of which } \\
\text { parent is a fan }\end{array}$ & Typology \\
\hline Amanda & Female & 45 & Staffordshire & $9 \& 13$ & Married & Football & Breather \\
\hline Simon & Male & 47 & West Yorkshire & $9 \& 12$ & Divorced & Football & Breather \\
\hline James & Male & 40 & North Lanarkshire & $3 \& 7$ & Married & Football & Breather \\
\hline Andrew & Male & 29 & Aberdeenshire & 5 & Married & Football & Breather \\
\hline Barbara & Female & 55 & Cleveland & $14 \& 17$ & Married & Football & Begrudger \\
\hline Elizabeth & Female & 38 & Shropshire & $5,7 \& 9$ & Married & Football & Begrudger \\
\hline Gillian & Female & 54 & Cheshire & $22 \& 25$ & Married & Football & Begrudger \\
\hline Keith & Male & 45 & Monmouthshire & 9 & Married & Football & Begrudger \\
\hline Carol & Female & $65+$ & Dorset & $39,42 \& 45$ & Married & Football & Bonder \\
\hline Laura & Female & 24 & West Sussex & $1 \& 9$ & Married & Football & Bonder \\
\hline Anna & Female & 35 & Cumbria & 4 & Living with partner & Football & Bonder \\
\hline Gemma & Female & 45 & Staffordshire & $10 \& 15$ (twins) & Married & Football & Bonder \\
\hline Patrick & Male & 45 & Northants & 12 & Divorced & Football & Bonder \\
\hline Oliver & Male & 50 & $\begin{array}{c}\text { Greater } \\
\text { Manchester }\end{array}$ & $21 \& 23$ & Married & Football & Bonder \\
\hline Gordon & Male & 55 & East Sussex & $2 \& 7$ & Married & Football & Bonder \\
\hline George & Male & 34 & Tyne and Weir & $8,14 \& 15$ & Married & Football & Bonder \\
\hline Lucy & Female & 20 & Kent & 1 & Living with partner & Football & Balancer \\
\hline Maureen & Female & 35 & Hertfordshire & $2 \& 5$ & Married & Football & Balancer \\
\hline Ralph & Male & 35 & Essex & 8 & Married & Football & Balancer \\
\hline Laurence & Male & 44 & Leicestershire & $19 \& 22$ & Married & Football & Balancer \\
\hline
\end{tabular}


Table 3

Parental Fandom Typology

\begin{tabular}{|c|c|c|c|}
\hline Typology & Description & Participant Pseudonyms & Examples \\
\hline \multirow{3}{*}{ Breathers } & \multirow{3}{*}{$\begin{array}{l}\text { Escape family life through fandom } \\
\text { Highly committed } \\
\text { Accept associated (financial) costs } \\
\text { View sport fandom as a necessity } \\
\text { Reflected failure hard to bear } \\
\text { No de-escalation and some escalation of } \\
\text { fandom as a consequence of transition }\end{array}$} & Alec & $\begin{array}{l}\text { The only things that ever stand in the way of going to the game } \\
\text { is if there is a big family problem or if I have work } \\
\text { commitments. Apart from that, I am at the games all the time. }\end{array}$ \\
\hline & & Colin & $\begin{array}{l}\text { I didn't give up completely [after the birth of my children], far } \\
\text { from it, it was maybe slightly curtailed, but it would largely } \\
\text { depend on if their mother was free to look after them so I could } \\
\text { go away. At that time I was working Monday to Friday, so the } \\
\text { weekends were my time off - that was when I got my leisure } \\
\text { time. }\end{array}$ \\
\hline & & Graeme & $\begin{array}{l}\text { I have been known to go home to my bed after my team loses. I } \\
\text { just don't want to be with other people. }\end{array}$ \\
\hline Begrudgers & $\begin{array}{l}\text { Reject associated costs } \\
\text { De-escalate fandom with age } \\
\text { De-escalation more permanent } \\
\text { Nostalgic } \\
\text { Time spent on other activities } \\
\text { Views shared by peers }\end{array}$ & Brendan & $\begin{array}{l}\text { It wasn't a conscious decision to stop going...I think when I did } \\
\text { have the opportunity to go back [to watching games at the } \\
\text { stadium] the match fixing, players getting a ridiculous sum to } \\
\text { kick a ball and ticket prices going through the roof...it didn't } \\
\text { feel the same. I lived for it when I was younger...but...I don't } \\
\text { think it is a place for the kids. And not me. Not anymore. }\end{array}$ \\
\hline
\end{tabular}




\section{Darren}

Sport fandom extension of family values Concerned with developing social networks

Bonders More likely to have resided in more than one country

Use overcoming 'failure' as an example

More eclectic in fandom behavior
I think the sport teaches camaraderie and respect, particularly in rugby as opposed to football, and I think that's good, especially for children to learn. It teaches kids the values of discipline, teamwork and respect.

I think [horse riding] has helped [my children] meet other people and enriched their social experience. It's helped lead them to adulthood in an environment where we could spend time together and has helped them to expand their social network outside of school. Sports has helped them make the most of every opportunity. There are a lot of life skills around liking sports that are really useful.

I remember explaining to my kids that if there is an unfair call in sport, you should not get angry about it because this is what happens out there in society. The world is full of unfairness and this can't be avoided in sports. When I became a parent I...became more responsible as a fan. In the past I have behaved badly at the stadium but since I started going with my kids I think about what I should sing and I avoid confrontation and swearing. Sport represents who we are as a family, not a particular team but sport in general.

Well, obviously family comes first so things got put on hold. I used to play the sports, golf and darts regularly, but that all went on hold until such time that my son was old enough and I didn't have the same responsibilities every week. When he was growing up, he took part in a lot of various sports which I would take him to, and I started watching him play them. My own interests were put on hold really whilst I took him to the things that he wanted to do. 
My fandom is not gone completely but I am getting older and I find myself doing other stuff now. I'd like my son to do sports, but I want to give him the choice to decide by himself. I would go out of my way to help him participate - even if I had to drive him somewhere, no problem. 